Article

\title{
Farmer Demand and Willingness-To-Pay for Sweetpotato Silage-Based Diet as Pig Feed in Uganda
}

\author{
Marsy Asindu ${ }^{1} * \mathbb{E}$, Emily Ouma ${ }^{2}$, Gabriel Elepu ${ }^{1}$ and Diego Naziri ${ }^{3,4}$ \\ 1 Department of Agribusiness and Natural Resources Economics, Makerere University, P.O. Box 7062, \\ Kampala, Uganda; gelepu@gmail.com \\ 2 International Livestock Research Institute (ILRI), Plot 106, Katalima Road, Naguru, P.O. Box 24384, \\ Kampala, Uganda; E.A.Ouma@cgiar.org \\ 3 International Potato Center (CIP), Hanoi 100000, Vietnam; D.Naziri@cgiar.org \\ 4 Natural Resources Institute (NRI), University of Greenwich, Chatham ME4 4TB, UK \\ * Correspondence: asimessy@gmail.com
}

Received: 16 June 2020; Accepted: 15 July 2020; Published: 11 August 2020

check for updates

\begin{abstract}
Smallholder livestock farmers across Sub-Saharan Africa are racing against time to find cheaper, nutritious, and sustainable feed alternatives to the more pronounced and expensive commercial concentrates amidst the increasing global demand for livestock products. Lately, many prominent feed conservation technologies have been developed, with a notable example being the sweetpotato silage technology that turns wasted sweetpotato components into a palatable and nutritious livestock feed. However, despite the potential benefits associated with these technologies, the level of demand and acceptance among smallholder farmers remains largely unknown. Thus, this paper assesses the farmer demand and willingness-to-pay (WTP) for sweetpotato silage-based diet as pig feed by smallholder farmers in Uganda. The information for the study was collected through secondary data review and semi-structured interviews to assess farmer WTP. The 256 semi-structured interviews were randomly drawn from 16 purposive clusters formed at a radius of $3 \mathrm{~km}$ around 16 farmers piloting sweetpotato silage-based diets for pig feed. The results show that pig farming is mainly the responsibility of women, with farmers' mean willingness-to-pay price amounting to 0.20 USD per kilogram of sweetpotato silage-based diet. At the mean price, the annual demand for silage was estimated at 17,679 tons, with a market potential of approximately 3.59 million USD. The study concludes that, at the mean willingness-to-pay price, there is a substantial market potential that can be exploited by small and medium-sized enterprises (SMEs) venturing in the livestock feed industry.
\end{abstract}

Keywords: sweetpotato; silage; demand; willingness-to-pay; food systems; Uganda

\section{Introduction}

Livestock contributes to food security by supplying $18 \%$ of global calories consumption and $25 \%$ of global protein consumption [1]. This contribution is expected to increase in many parts of the world due to rising incomes, growing population, and urbanization [2]. Current estimates indicate that global demand for meat and milk is expected to increase by $57 \%$ and $48 \%$, respectively, between 2005 and 2050 [2]. However, efforts to meet this projected demand will be highly compromised by high feed costs and pronounced feed scarcity, which may eventually result in major impacts on global food systems and land use, as farmers will be forced to feed their animals on feed rations containing products that would otherwise be used for human consumption [3]. Similarly, animal feed production will be conducted on land suitable for human food production, thus resulting into feed/food competition [3]. To address these potential challenges, many global efforts on food security have focused on promoting 
technologies that can sustainably convert non-human edible feed materials and crop residues into animal feeds.

In Uganda, a study conducted by Asindu et al. [4] showed that substantial amounts of sweetpotato vines (599 kg/acre/season) and roots (125 kg/acre/season) were wasted. This wastage is known to present an excellent opportunity for small and medium-sized enterprises (SMEs) to invest in the sweetpotato silage business for livestock feeds [4]. Among varying livestock products, pork has become an increasingly important animal source food in the diets of many Ugandans [5]. In the 1960 s, pork accounted for only $1-2 \%$ of the per capita consumption of meat (11-12 kg/year); however, from the late 80 s, there was a sharp rise in pork demand (Figure 1).

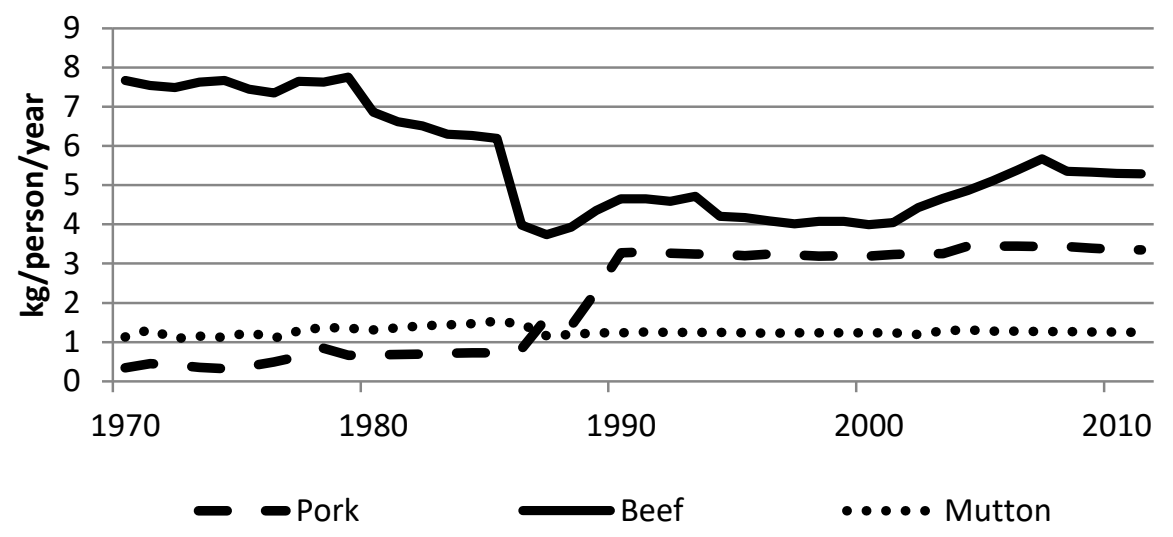

Figure 1. Trends in per capita consumption of beef, pork, and mutton, 1970-2011 (FAOSTAT, 2015).

As a result of this rise, pork now accounts for at least one third of the $10 \mathrm{~kg}$ of meat consumed per capita per year [6]. This high demand for pork has resulted in increased pig production, that is evidenced by a sharp increase in the pig population over the last 30 years, from 0.12 million in 1970s to 3.2 million in 2008 [7]. Following this trend, pig production has become an increasingly important livelihood source for smallholder farmers in Uganda. High feed costs, however, have become a major constraint, representing 60 to $80 \%$ of the total cost of production, with commercial concentrates as the most expensive of all available feeds [8]. In a bid to minimise high feed costs and create a balanced feed ration, smallholder pig farmers have resorted to using locally available on-farm feeds, notably fresh sweetpotato vines, peelings, and non-marketable roots supplemented with maize bran. But this combination still does not yield a balanced diet, resulting in low average daily weight gains [9]. Additionally, the seasonality and high perishability, compounded by a lack of awareness of processing technologies for conserving the vines during the dry season, limits the use of sweetpotatoes as animal feed to the wet seasons and creates situations of feed scarcity during the dry seasons.

Several agricultural research institutions have been testing sweetpotato silage-based diets for pigs to overcome the dry season feed shortages [10-12]. Sweetpotato silage has been noted to offer potential business opportunities to SMEs [4]. However, there exists an information gap regarding farmer demand, farmer willingness-to-pay (WTP) for the sweetpotato silage-based diet, and the economic feasibility of using sweetpotato silage-based diet for pig feeding. This study, therefore, aims to assess the economic feasibility, demand, farmer willingness-to-pay, and market potential of sweetpotato silage-based diet in major pig production districts in Uganda. The findings will be useful to stakeholders involved in promoting smallholder pig value chains and the use of sweetpotato as pig feed. 


\section{Material and Methods}

\subsection{Study Sites and Study Design}

The study was conducted in the Masaka and Kamuli districts, which are in the central and eastern regions of Uganda, respectively. The two districts were purposely selected for their high levels of pig and sweetpotato production. Furthermore, several programmes aimed at boosting pig and sweetpotato production have been implemented in these two districts by several international and national (local) agricultural research institutions.

A total of 256 pig farmers were randomly selected from 16 purposive clusters. These clusters were formed at a radius of $3 \mathrm{~km}$ around each of the 16 farmers piloting the use of sweetpotato silage as pig feed in Kamuli and Masaka. Interviews were conducted using a semi-structured questionnaire containing a series of open- and close-ended questions in August and September 2016.

The questionnaire used included questions about farmers' demographic characteristics, their perceptions of using sweetpotato silage-based diet as pig feed, their willingness-to-pay, and the market potential of sweetpotato silage-based diet.

\subsection{Estimation of Farmer Perceptions towards Sweetpotato Silage-Based Diet as Pig Feed}

The perceptions of farmers regarding the use of sweetpotato silage-based diet as pig feed were measured using a five-point Likert scale. For instance, respondents were asked if they agreed or disagreed with 10 statements on the cost and benefits of sweetpotato silage-based diet technology. Five statements were designed to capture the economic benefit perceptions of the respondents, two were used to capture pig performance perceptions, and one statement each for risk and safety perceptions, complexity perceptions, and technology cost perceptions. The Likert scale responses were assigned scores ranging from -1 for "strongly disagree" to -0.5 for "disagree", 0 for "neutral", 0.5 for "agree", and 1 for "strongly agree" [13]. For each category with two or more statements (pig performance perceptions and economic benefit perceptions), we generated an associated Cronbach's alpha ( $\alpha$ ) to measure the reliability and internal consistency of the statements. The analysis of the data involved the use of descriptive statistics, including means and standard deviations, to characterize farmers. $t$-tests were also conducted to establish any significant differences in perceptions between the respondents who were aware of the sweetpotato silage-based diet technology and those who were not aware of it.

\subsection{Theoretical and Analytical Framework}

In this study, we used the double bounded willingness-to-pay (WTP) method. WTP is a stated preference method that involves asking consumers directly, in a hypothetical survey, the maximum amount they are willing-to-pay for a good or service that has been offered [14]. The contingent valuation method (CVM) has been used by economists for approximately thirty years to value changes in natural resources and the environment. In several other cases, CVM has been used to evaluate farmers' preferences for crop attributes and other technical innovations, particularly where revealed preference approaches are not feasible. For this reason, CVM is ideal when it comes to measuring the value of non-market goods [15].

The underlying framework for WTP is based on utility maximisation. Let $\mathrm{U}(\mathrm{X})$, be an individual preference function where $\mathrm{X}=x_{1}, \ldots \ldots \ldots . . ., x_{n}$ is a vector of private goods available at market prices:

$$
p=p_{1, \ldots \ldots \ldots . . . . .} p_{n}
$$

The individual maximises utility subject to an income constraint, $y$, and the indirect utility function is given by:

$$
V(p, y)=\max \{u(x) \mid p \cdot x \leq y\}
$$


The minimum expenditure function is dual to the indirect utility function and is given as:

$$
\mathrm{m}(p, u)=\min \{p \cdot x \mid U(x) \geq u\}
$$

The derivative of the expenditure function with respect to price then gives the Hicksian or utility-constant demand, where the subscript indicates a partial derivative.

$$
x_{i}^{u}(p, q, u)=m_{p i}(p, q, u)
$$

The negative ratio of derivatives of the indirect utility function with respect to price and income then gives the Marshallian or ordinary demand curve.

$$
x_{i}(p, q, y)=-V_{p i}(p, q, y) V_{y}(p, q, y)
$$

An individual will therefore be willing to pay for a good if it maximises his utility function, subject to an income constraint.

This study applied the double-bounded CVM elicitation technique. Hanemann et al. [16] show that this method improves the efficiency of a willingness-to-pay study by offering the respondent a second bid, lower or higher depending on the first response. It further incorporates more information about an individual's WTP and, therefore, provides more efficient estimates and tighter confidence intervals than open- and close-ended formats. Open-ended formats often tend to be problematic, since the respondent might not have sufficient information and stimuli to thoroughly consider the values they would attach to a good if a market existed, and thus might not return realistic estimates [17]. Close-ended questions, on the other hand, are incentive-compatible in that it becomes the respondent's strategic interest to say yes if her/his WTP is greater or equal to the price asked and not otherwise [18]. This approach requires a large sample size and its statistical efficiency is not very high [16].

The operationalization of the double-bounded CVM technique began with enumerators first describing and presenting pictorial illustrations of sweetpotato silage-based diet to the respondents before obtaining data on their WTP. This step was executed to create awareness, because the product was new and not yet known by all respondents. Six bids were converted from local currency to US dollars (USD) at one Ugandan shilling (UGX) to 0.0003 USD, and then randomly distributed to different respondents. The six bids selected for use were: USD 0.06, USD 0.1, USD 0.15, USD 0.19, USD 0.24 , and USD 0.3 per kilogram $(\mathrm{kg})$. The bid prices were chosen based on results from pre-testing in which 30 respondents were asked how much they were willing to pay per kilogram of sweetpotato silage-based diet using the double bounded CVM approach. During the pre-test, a pre-determined initial bid price of USD 0.22 per $\mathrm{kg}$ of sweetpotato silage-based diet was allocated to every respondent. This initial bid price was obtained by calculating the breakeven price for a kilogram of sweetpotato silage-based diet (Table 1). An additional amount of USD 0.05 was then included to account for the entrepreneurs' costs of storage, transport, and profit.

Table 1. Calculation of the breakeven price for sweetpotato silage-based pig diet.

\begin{tabular}{ccc}
\hline Ingredients & Cost per Kilogram (USD) & $\begin{array}{c}\text { Cost/kg of Silage-Based Pig Diet } \\
\text { (600 gm Sweetpotato Silage and } \\
\text { 400 gm Supplement (USD) }\end{array}$ \\
\hline Sweetpotato silage & 0.06 & 0.04 \\
Supplement & 0.33 & 0.13 \\
Total & & $\mathbf{0 . 1 7}$ \\
\hline
\end{tabular}

Source: Field data 2016. 
Using double bounded CVM, farmers were then presented with the initial bid of USD 0.22 per $\mathrm{kg}$ of sweetpotato silage-based diet. If the farmer's response to the initial bid price was "no", USD 0.01 were subtracted, and a second bid was presented. This went on until the farmer responded with a "yes". If a farmer agreed to the initial bid price, USD 0.01 were subtracted, and a second bid was presented. This went on until the farmer responded with a "no". The price at which the farmer said "yes" was then taken as his/her WTP.

From the pre-test results, the lowest price $/ \mathrm{kg}$ respondents were willing to pay for sweetpotato silage-based diet was USD $0.06 / \mathrm{kg}$, and the highest WTP was USD $0.3 / \mathrm{kg}$. Therefore, USD $0.06 / \mathrm{kg}$ and USD $0.3 / \mathrm{kg}$ were chosen as the lowest and highest price, respectively. The same method was used by Hall et al. [19] to determine bid values, based upon results from pre-testing. They used open-ended questions which gave them values from USD 0 to USD 260. They chose to place a bid from USD 2 up to USD 100.

Depending on the response to the initial bid that was randomly offered, if the survey participant responded with a "yes", a follow-up bid double the initial value was offered. Likewise, if the survey participant responded with a "no" to the initial bid price randomly offered, a second follow up bid half the initial value was offered (Table 2).

Table 2. Alternative bids for the sweet potato silage-based diet.

\begin{tabular}{ccc}
\hline B (USD) & $\mathbf{B}^{\mathbf{d}}$ (USD) & $\mathbf{B}^{\mathbf{u}}$ (USD) \\
\hline 0.06 & 0.03 & 0.12 \\
0.10 & 0.05 & 0.21 \\
0.15 & 0.07 & 0.30 \\
0.19 & 0.10 & 0.39 \\
0.24 & 0.12 & 0.48 \\
0.30 & 0.15 & 0.60 \\
\hline
\end{tabular}

Note: $B$ is the initial bid; $B$ is the second bid if the response to the first bid was "no", and Bu is the second bid if the response to the first bid was "yes".

Thus, there were four possible outcomes to the questions: (a) both answers are "yes"; (b) both answers are "no"; (c) a "yes" followed by a "no"; and (d) a "no" followed by a "yes." [13]. These four probabilities are then denoted as follows:

$$
\begin{gathered}
\operatorname{Pryy}\left(B, B^{u}\right)=\operatorname{Pr}\left[B \leq W T P, B^{u} \leq W T P\right]=\operatorname{Pr}\left[B \leq W T P \mid B^{u} \leq W T P\right] \operatorname{Pr}\left[B^{u} \leq W T P\right] \\
=\operatorname{Pr}\left[B^{u} \leq W T P\right]=1-F\left(B^{u}\right) \\
\operatorname{Pryn}(B, B \dot{u})=\operatorname{Pr}[B \leq W T P<B u]=F(B \mathfrak{u})-F(B) \\
\operatorname{Prny}\left(B, B^{d}\right)=\operatorname{Pr}\left[B^{d} \leq W T P<B\right]=F(B)-F\left(B^{d}\right) \\
\operatorname{Prnn}\left(B, B^{d}\right)=\operatorname{Pr}\left[B>W T P, B^{d}>W T P\right]=F\left(B^{d}\right)
\end{gathered}
$$

where Pryy: probability of answering "yes" "yes"; Pryn: probability of answering "yes" "no"; Prny: probability of answering "no" "yes"; and Prnn: probability of answering "no" "no"; B: price in the first question; $\mathrm{B}^{\mathrm{u}}$ : higher price in the second question; $\mathrm{B}^{\mathrm{d}}$ : lower price in the second question; WTP: willingness-to-pay; and F: cumulative distribution function (CDF).

Combining the probabilities of the four outcomes, the log-likelihood function $(\ln L)$ for a sample then takes the form:

$$
\ln L=\sum_{1}^{N}\left\{y y_{i} \ln \operatorname{Pr}_{y y}\left(B_{i}, B_{i}^{U}\right)+y n_{i} \ln \operatorname{Pr}_{y n}\left(B_{i}, B_{i}^{U}\right)+n y_{i} \ln P r_{n y}\left(B_{i}, B_{i}^{d}\right)+n n_{i} \ln \operatorname{Pr}_{n n}\left(B_{i}, B_{i}^{d}\right)\right\}
$$


where $y y, y n, n y$, and $n n$ are dummy variables. If one respondent says yes-yes ( $y y)$ to two questions, then $y y=1$, otherwise it will be zero. Kimenju and De Groote [20] point out that the parameter could be estimated by maximising the likelihood function. The mean WTP was then evaluated using the following equation, adopted from Shultz and Soliz [21]:

$$
\text { Mean WTP }=\beta_{0}+\frac{\sum \beta_{2} \times_{2} \ldots \ldots \ldots \ldots \beta_{k} \times{ }_{k}}{-\beta_{1}}
$$

where $\beta_{0}$ is the estimated constant; $\beta_{k}$ are the estimated co-efficient parameters; $\times_{k}$ are the mean values of the explanatory variables; and $\beta_{1}$ is the estimated co-efficient of the bid.

\subsection{Factors That Influence the Willingness to Pay for Sweetpotato Silage-Based Diet as Pig Feed}

A binary logit regression model was fitted to assess the factors that influence the farmers' willingness to pay for sweetpotato silage-based diets. Following Chen and Chern [22] and Kimenju and Hugo [13], a logit model was specified to examine the relationship between WTP and socio-economic variables, price, and perceptions about the product. Formally, the binary logistic model explaining consumers' WTP is specified as:

$$
W T P=\propto+\rho \beta+\varnothing Z+\varepsilon
$$

where WTP is the willingness-to-pay $\{1$ if the consumer is willing to pay for sweet potato silage-based diet and 0 otherwise $; \beta \beta$ is the bid price; $Z$ is a vector of explanatory variables; $\alpha, \rho, \varnothing$ are vectors of unknown coefficients; and $\varepsilon$ is the identically, independently distributed variable with zero mean.

The variables used in the binary logit model are presented in Table 3. Most of these explanatory variables were selected based on theory and previous studies. For example, the bid price was expected to have a significant negative effect on farmers' willingness to pay for sweetpotato silage-based diet following the theory of demand and supply, which indicates that price is inversely related to demand. Credit was treated as a liquidity constraint, while age was linked to the lifecycle hypothesis in technology adoption. The education level of the farmers was linked to the human capital theory, which states that skills are learnt or acquired, and that skills enhance the conceptualization of ideas. The number of pigs sold, the land under sweetpotato production, and the access to credit were assumed to be wealth indicators that have impact on the farmers' decision-making process. Lastly, the extension was linked to exposure and collective learning.

\subsection{Estimation of Market Potential for Sweetpotato Silage-Based Diet}

The number of potential buyers (households) for sweetpotato silage-based diet was obtained based on the population estimates for the Masaka and Kamuli districts in 2014. The National Population and Housing Census conducted by Uganda Bureau of Statistics (UBOS) [7], in 2014 estimated 75,306 and 93,789 households in Masaka and Kamuli, respectively, for a total of 169,195 households in the two districts combined. According to the national livestock census report [7], 42.3\% and $15.5 \%$ of the households in Masaka and Kamuli, respectively, are involved in pig rearing. These figures indicate a total of 31,854 and 14,537 pig-rearing households in the two districts, respectively. Further analysis of the primary data collected indicated that $43 \%$ of the pig rearing households in Masaka and $47 \%$ in Kamuli expressed a willingness-to-pay above the mean price of USD 0.20 per $\mathrm{kg}$ of silage-based diet. This finding indicated a potential buying population of 13,697 and 6833 pig-rearing households for Masaka and Kamuli, respectively. 
Table 3. Variables employed in the logit model and their influence on farmers' willingness-to-pay (WTP).

\begin{tabular}{ccc}
\hline Variable & Description & A Priori Signs \\
\hline $\mathrm{Y}_{1}$ & Willingness-to-pay (WTP) & Yes $=1$, No = 0 \\
$\mathrm{B}_{1}$ & Bid price (USD) & - \\
$\mathrm{X}_{1}$ & Silage technology awareness (yes/no) & $+/-$ \\
$\mathrm{X}_{2}$ & Pig production experience (years) & + \\
$\mathrm{X}_{3}$ & Pig management system (tethered/not tethered) & $+/-$ \\
$\mathrm{X}_{4}$ & Distance to nearest feed market $(\mathrm{km})$ & - \\
$\mathrm{X}_{5}$ & Economic benefit perception (index) & + \\
$\mathrm{X}_{6}$ & Pig breed kept (local/improved) & + \\
$\mathrm{X}_{7}$ & Access to credit (yes/no) & + \\
$\mathrm{X}_{8}$ & Access to extension services (yes/no) & + \\
$\mathrm{X}_{9}$ & Number of pigs sold in the last year & + \\
$\mathrm{X}_{10}$ & Land under sweetpotato production (acres) & $+/-$ \\
$\mathrm{X}_{11}$ & Farmer's years of schooling (years) & + \\
$\mathrm{X}_{12}$ & District of farmer (Masaka/Kamuli) & $+/-$ \\
\hline
\end{tabular}

Source: literature review.

Considering the fact that the average annual demand for sweetpotato silage-based diet was 0.955 and 0.673 tons per household in Masaka and Kamuli, respectively, the overall annual demand for each district was then derived by multiplying the average annual demand for sweetpotato silage-based pig diet per household by the number of households willing to pay the mean price and above. The market potentials for both Masaka and Kamuli were then computed using the formula below, as derived by Wolfe [23].

$$
\mathrm{MP}=N \times P \times A
$$

where MP: market potential; $N$ : number of possible buyers at price $P$; $P$ : mean willingness-to-pay or average selling price; and $A$ : average annual consumption. Since the price of a commodity is a key driver of demand and supply in the market, further analysis explored the effect of increasing or decreasing the mean price of sweetpotato silage-based pig diet on its demand and supply.

\section{Results}

\subsection{Socio-Economic and Demographic Characteristics of Surveyed Pig Farmers}

Descriptive statistics of the variables and the analytical results of the differences in the means obtained through t-tests are presented in Table 4 . The significance levels suggest some differences between the Kamuli and Masaka districts. For instance, pig farmers from Kamuli were shown to be older than those in Masaka. Similarly, there were more male pig farmers in Kamuli than in Masaka. The mean household size in the study area was 5.3, with more members per household in Kamuli compared to Masaka. A typical household owned an average of four mature pigs. However, pig-farming households in Masaka owned almost twice the number of pigs than those in Kamuli. Compared to Kamuli, pig farmers in Masaka had attained a higher level of education.

Results also showed that farmers in Masaka owned more improved pig breeds that produce and mature faster compared to the local breeds that were dominant in Kamuli. Farmers in Masaka also sold a higher number of pigs each year and earned more income (USD 199) from pig sales than their counterparts in Kamuli (USD 85.4). Significant differences were also present in both the total farm size and the land allocated to sweetpotato production. Farmers in Masaka owned smaller land sizes on average ( 3.4 acres) compared to their counterparts in Kamuli ( 4.3 acres). This difference likely explains why farmers in Masaka allocated less land to sweetpotato production ( 0.96 acres) than farmers in Kamuli (1.19 acres) and not all were able to engage in sweetpotato production, unlike their Kamuli counterparts. Regarding the contact with extension agents, $45 \%$ of pig farmers in Masaka had been visited in connection to pig production compared to $38 \%$ in Kamuli. Piggery is a priority enterprise 
in Masaka, as indicated in the district agricultural plan. More resources were allocated to piggery and its support services, mainly extension. This difference also strongly accounts for why most of the pig farmers in Masaka were aware of the silage technology compared to their colleagues in Kamuli (Table 4).

Table 4. Socio-economic and demographic attributes of pig farmers.

\begin{tabular}{ccccc}
\hline Farmer Characteristic & Total $(\boldsymbol{N}=\mathbf{2 5 6})$ & Masaka $(\boldsymbol{n = 1 2 8 )}$ & Kamuli $(\boldsymbol{n}=\mathbf{1 2 8})$ & $\boldsymbol{t}$-Value \\
\hline Farmer age (years) & $46.14(14.09)$ & $45.47(15.09)$ & $46.81(12.98)$ & $3.15^{* * *}$ \\
Household number (persons) & $5.33(2.40)$ & $4.66(2.13)$ & $6.00(2.46)$ & $19.28^{* * *}$ \\
Sex (Male) (\%) & 41.77 & 39.06 & 44.49 & $3.63^{* * *}$ \\
Farmer years of schooling & $8.19(3.58)$ & $8.99(3.53)$ & $7.38(3.45)$ & $-15.25^{* * *}$ \\
Years of experience in pig keeping & $12.43(0.66)$ & $12.16(0.87)$ & $12.70(0.98)$ & -0.40 \\
Pig units owned & $3.60(4.79)$ & $4.39(6.16)$ & $2.81(2.60)$ & $-11.01^{* * *}$ \\
Local pig breeds (\%) & 40.63 & 25.78 & 55.47 & $-5.05^{* * *}$ \\
Pig management system (tethered \%) & 35.94 & 10.16 & 61.72 & $-10.15^{* * *}$ \\
Access to credit (\%) & 7.42 & 8.59 & 6.25 & 0.71 \\
Access to extension services (\%) & 41.41 & 44.53 & 38.28 & $-4.19^{* * * *}$ \\
Membership of pig producer group (\%) & 27.73 & 28.13 & 27.34 & -0.58 \\
Distance to nearest feed market (km) & $2.46(2.22)$ & $2.56(2.51)$ & $2.36(1.89)$ & $-3.07^{* * *}$ \\
Number of pigs sold in the last year & $3.90(0.45)$ & $4.70(0.82)$ & $3.10(0.38)$ & $1.77^{*}$ \\
Silage technology awareness (\%) & 64.43 & 71.09 & 57.77 & $-9.27^{* * *}$ \\
Farmer grows sweetpotato (\%) & 94.53 & 89.06 & 100.00 & $16.34^{* * *}$ \\
Farm size (acres) & $3.88(2.88)$ & $3.43(3.08)$ & $4.33(2.58)$ & $10.46^{* * *}$ \\
Land under sweetpotato (acres) & $1.07(0.03)$ & $0.96(0.05)$ & $1.19(0.04)$ & $-3.64^{* * * *}$ \\
Annual pig income (USD) & $142.20(289.70)$ & $199.00(378.19)$ & $85.41(135.70)$ & $-13.19^{* * *}$ \\
\hline Source surv dat
\end{tabular}

Source: survey data 2016, Note: Figures in brackets are standard deviations. ${ }^{*},{ }^{* * *}$ denote significance at $p=0.1$ and 0.01 levels, respectively.

\subsection{Farmer Perceptions towards the Use of Sweetpotato Silage-Based Diet as Pig Feed}

Results from the analysis show that farmer perceptions on different aspects related to sweetpotato silage were mostly positive (Table 5). Notable examples included the perceptions on pig performance and economic benefits, which are essential to motivate the farmers' willingness to pay for sweetpotato silage-based diet. Farmers who were aware of the silage technology had a very positive perception, comparatively, when it came to the silage's ability to save labour and time, improve pig growth, and provide high palatability to the pigs. The difference in perception between the two categories of farmers can be attributed to the fact that those exposed to the silage technology had witnessed the extra weight gain that resulted from feeding pigs with a sweetpotato silage-based diet, the attraction of pigs to the feed, and the reduced time and labour required to prepare enough feed for a pig throughout its entire growth span.

The responses on the technology costs-especially the perception of the silage motorized chopping machine as expensive (about USD 700)-indicated negative perceptions that could eventually demotivate farmers to adopt the technology. In terms of safety, farmers who had not heard of nor seen the silage chopper machine thought that it could be risky and unsafe if not properly handled, compared to their counterparts, who had not been exposed to the chopper machine. These variations in perception arose because some of the farmers who were exposed to, or had heard of, the silage-making process reported that some individuals were injured in the process of chopping vines. 
Table 5. Pig farmers' perceptions on sweetpotato silage-based diet as pig feed.

\begin{tabular}{|c|c|c|c|c|}
\hline Perception on Statement & $\begin{array}{c}\text { Aware of the } \\
\text { Technology }(n=164)\end{array}$ & $\begin{array}{l}\text { Not Aware of the } \\
\text { Technology }(n=92)\end{array}$ & $\begin{array}{l}\text { Overall Mean } \\
\text { Score }(n=256)\end{array}$ & $t$-Value \\
\hline \multicolumn{5}{|l|}{ Economic benefit } \\
\hline Silage use is labour and time saving & $0.78(0.27)$ & $0.71(0.28)$ & $0.76(0.27)$ & $-2.18^{* *}$ \\
\hline Silage eliminates feed scarcity & $0.77(0.27)$ & $0.78(0.25)$ & $0.77(0.26)$ & 0.26 \\
\hline Silage is money saving & $0.78(0.25)$ & $0.76(0.25)$ & $0.77(0.25)$ & -0.77 \\
\hline Silage-making creates employment & $0.77(0.36)$ & $0.71(0.32)$ & $0.74(0.34)$ & -1.32 \\
\hline Silage reduces root and vine wastage & $0.77(0.28)$ & $0.80(0.25)$ & $0.79(0.27)$ & 0.85 \\
\hline Economic benefit perception index & $0.77(0.19)$ & $0.75(0.19)$ & $0.77(0.19)$ & -0.97 \\
\hline \multicolumn{5}{|l|}{ Pig performance } \\
\hline Silage improves pig growth & $0.75(0.35)$ & $0.62(0.24)$ & $0.70(0.32)$ & $-3.12 * * *$ \\
\hline Silage is very palatable & $0.69(0.35)$ & $0.58(0.32)$ & $0.65(0.34)$ & $-2.36 * *$ \\
\hline Pig performance index & $0.72(0.30)$ & $0.60(0.24)$ & $0.67(0.28)$ & $-3.19 * * *$ \\
\hline \multicolumn{5}{|l|}{ Technology cost } \\
\hline Silage chopper is not very expensive & $-0.56(0.71)$ & $-0.66(0.67)$ & $-0.59(0.70)$ & -1.10 \\
\hline Technology cost index & $-0.56(0.71)$ & $-0.66(0.67)$ & $-0.59(0.70)$ & -1.10 \\
\hline \multicolumn{5}{|l|}{ Risk and safety } \\
\hline Silage chopper is safe and not risky to use & $0.02(0.75)$ & $0.22(0.70)$ & $0.09(0.74)$ & $2.08^{* *}$ \\
\hline Risk and safety index & $0.02(0.75)$ & $0.22(0.70)$ & $0.09(0.74)$ & $2.08^{* *}$ \\
\hline \multicolumn{5}{|l|}{ Complexity } \\
\hline Silage is easy to prepare & $0.55(0.66)$ & $0.55(0.62)$ & $0.55(0.65)$ & -0.07 \\
\hline Complexity index & $0.55(0.66)$ & $0.55(0.62)$ & $0.55(0.65)$ & -0.07 \\
\hline
\end{tabular}

Note: Numbers in parentheses are standard deviations. ${ }^{* *},{ }^{* *}$ denote significance at $p=0.05$ and 0.01 levels, respectively.

\subsection{Farmers' Willingness to Pay for Sweet Potato Silage-Based Diet}

The mean willingness-to-pay price for a kilogram of sweetpotato silage-based feed was estimated using a logistic analysis. The analysis found that the mean WTP was USD 0.20/kg (Table 6). This figure corresponds to approximately UGX 679, considering an exchange rate of 1 UGX $=0.0003$ USD at the time of the survey.

Table 6. Krinsky and Robb (95\%) Confidence Interval for WTP measures.

\begin{tabular}{cccccc}
\hline Measures & WTP & LB & UB & ASL $^{*}$ & CI/MEAN \\
\hline Mean/Median & 0.20 & 0.19 & 0.22 & 0.0000 & 0.12 \\
\hline
\end{tabular}

Note: ASL * is the Achieved Significance Level for testing; H0: WTP < = 0 vs. H1: WTP > 0; LB is the lower bound; UB is the upper bound.

\subsection{Factors Influencing Farmers' Willingness to Pay for Sweetpotato Silage-Based Pig Feed}

To determine the factors that influenced farmers' willingness to pay for silage-based diet as pig feed, a binary logit model was estimated, and the size of the effects was gauged by analysing the marginal effects of the exploratory variables, which included, among others, bid price, silage technology awareness, years of experience in pig production, pig management system, distance to the nearest feed market, economic benefit perception index, pig breed kept, access to credit, access to extension services, number of pigs sold in the last year, land under sweetpotato production, farmers' level of education, and farmers' district of origin. The binary logit model was used because the willingness-to-pay had two outcomes (1-willing, 0 -not willing). The results of the modelling effort are presented in Table 7 . 
Table 7. Logit model estimates for the factors influencing famers' willingness to pay for sweetpotato silage-based diet as pig feed.

\begin{tabular}{cccc}
\hline Variables & Marginal Effects & Standard Error & $p$-Value \\
\hline Bid price (USD) & -0.00 & 0.00 & 0.00 \\
Silage technology awareness (yes) & -0.24 & 0.08 & 0.00 \\
Pig production experience (years) & 0.01 & 0.00 & 0.10 \\
Pig management system (tethered) & -0.04 & 0.13 & 0.79 \\
Distance to the nearest feed market (km) & -0.01 & 0.02 & 0.50 \\
Economic benefit perception (index) & 0.91 & 0.27 & 0.00 \\
Pig breed kept (local) & 0.27 & 0.09 & 0.00 \\
Access to credit (yes) & 0.01 & 0.18 & 0.95 \\
Access to extension services (yes) & -0.04 & 0.10 & 0.70 \\
Number of pigs sold last year (numbers) & 0.01 & 0.01 & 0.20 \\
Land under sweetpotato production (acres) & 0.16 & 0.09 & 0.09 \\
Farmer's level of education (years) & -0.02 & 0.01 & 0.08 \\
Farmer's district of origin (Kamuli) & -0.16 & 0.11 & 0.15 \\
Statistics & & & \\
Number of observations & & & 256 \\
LR chi2(13) & & & 178.96 \\
Prob > chi2 & & & -83.81 \\
Log likelihood & & & 0.52 \\
Pseudo R2 & & &
\end{tabular}

Source: survey data 2016 .

As shown in Table 7, the single most important factor influencing the willingness-to-pay was the economic benefit perception index. An increase in the economic benefit perception index by 1 increased farmers' willingness to pay for sweetpotato silage-based diet, at the mean price, by $91.4 \%$. Aside from the economic benefit perception index, farmers who owned local pigs had a $27 \%$ higher likelihood of willingness to pay for sweetpotato silage-based diet. The variable related to the farmer' years of experience in pig production was also positive and significant at the $10 \%$ level. A one-year increase in farmers' experience in pig production raised the probability of their willingness to pay for sweetpotato silage-based diet by $0.6 \%$. The land under sweetpotato production also played an important role in positively influencing farmers' willingness to pay for silage-based diet as pig feed. An increase in the land area under sweetpotato by one unit lead to an increase in the likelihood of farmers' willingness to pay for sweetpotato silage-based diet by $16 \%$.

On the other hand, the variable representing the bid price negatively influenced farmers' willingness to pay for sweetpotato silage-based diet. The negative and statistically significant coefficients on bid price suggested that an increase in the bid price by USD 1 reduced the likelihood of farmers' willingness to pay for sweetpotato silage-based diet by $2 \%$. Silage technology awareness was another variable that negatively and significantly influenced farmers' willingness to pay for silage-based diet $(p=0.002)$. This finding implies that farmers who were aware of the silage technology were less likely to say "yes" to the bid price than those who were not aware. Lastly, among the factors that negatively influenced farmers' willingness to pay for sweetpotato silage-based diet were the years of schooling. The study found that an increase in farmers' years of schooling by one year decreased the willingness-to-pay probability by $2 \%$. Finally, among the factors tested, the number of pigs sold by a farmer in the last year, the pig management system, the distance to the nearest feed market, the access to extension services in relation to pig production in the last year, the access to credit, and the farmers' district of origin did not significantly influence their willingness to pay for sweetpotato silage-based pig diet.

\subsection{Estimated Market Potential for Sweet Potato Silage-Based Diets}

The results revealed that the overall potential demand for sweetpotato silage-based pig feed for the two districts stood at 17,679 tons annually, and the potential annual demand for silage-based diet 
for the Masaka district (13,081 tons) was almost three times that of the Kamuli district (4598 tons). This difference in demand can be attributed to the fact that farmers in Masaka owned more pigs compared to farmers in Kamuli. Furthermore, the sites in Masaka where data collection took place are densely populated with farmers owning small farmlands from which they can obtain limited feeds for pigs, thus resorting to buying feed ingredients, whereas in Kamuli farmers are characterized by having larger farmlands, which can provide considerable amounts of local feed for their pigs (Table 4).

The calculations further revealed a potential annual revenue of USD 3.59 million per year, given that the mean WTP price for the sweetpotato silage-based diet was USD 0.20 per kilogram (Table 8).

Table 8. Market potential for sweetpotato silage-based pig diet in the Masaka and Kamuli districts.

\begin{tabular}{cccc}
\hline Parameters & \multicolumn{3}{c}{ Districts } \\
\cline { 2 - 4 } & Masaka & Kamuli & Total \\
\hline Household number & 75,306 & 93,789 & 169,195 \\
Percentage of households keeping pigs & 42.3 & 15.5 & \\
$\quad \begin{array}{c}\text { Number of households keeping pigs } \\
\text { Percentage of households willing to pay the } \\
\text { mean price and above }\end{array}$ & 31,854 & 14,537 & 46,391 \\
$\begin{array}{c}\text { Number of households willing to pay the } \\
\text { mean price and above }\end{array}$ & 43 & 47 & \\
$\begin{array}{c}\text { Annual demand per household (tons) } \\
\text { Annual demand per district (tons) }\end{array}$ & 0.96 & 0.67 & \\
$\begin{array}{c}\text { Market potential per district (million USD) } \\
\text { Market potential at USD 0.2 mean WTP } \\
\text { price/kg }\end{array}$ & $13,081.03$ & 4598.29 & $17,679.32$ \\
\hline
\end{tabular}

Note: 1 UGX $=0.0003$ USD at the time the study was conducted.

The results show that increasing the WTP price of sweetpotato silage-based pig diet by $7 \%$ (USD 0.01) from an initial price of USD 0.21 results in a $6 \%$ decrease in the number of potential buyers and an increase in market potential of USD 0.04 million. This increase in market potential is attributed to the fact that the price increase outweighed the decrease in the number of potential buyers. However, further increases in the price of sweetpotato silage-based diet by 14\% (USD 0.03), 21\% (USD 0.04), and 29\% (USD 0.06), respectively, resulted in decreases in market potential by $32 \%$ (USD 1.2 million), $54 \%$ (USD 1.99 million), and 68\% (USD 2.51 million), respectively. In these cases, the decrease in the number of potential buyers outweighed the price increases.

In the scenarios where the price of sweetpotato silage-based diet decreased by $7 \%, 14 \%, 21 \%$, and $28 \%$, these figures resulted in a gradual increase in the number of potential buyers in both the Masaka and Kamuli districts (Table 9). This finding is in line with the law of demand, which indicates that price is inversely related to the quantity demanded. However, at the $7 \%, 14 \%$, and $21 \%$ price decrease marks, the market potential decreased by $-2 \%,-5 \%$ and $-11 \%$, respectively. This negative trend is explained by the fact that the decrease in price of the sweetpotato silage-based pig diet outweighed the increase in the number of potential buyers. It is interesting to note that a $29 \%$ price decrease, the market potential shot up by 35\% (USD 1.28 million). This occurred because the decrease in price far outweighed the increase in the number of potential buyers. To a silage producer, however, it does not make economic sense to take advantage of the market potential resulting from the $29 \%$ decrease in the price of sweetpotato silage-based pig diet. In fact, at these prices, the cost of producing sweetpotato silage-based pig diet (USD 0.17 per $\mathrm{kg}$ ) would exceed the selling price, resulting in negative profit margins for the entrepreneur. 
Table 9. Effect of price change on the market potential of sweetpotato silage-based pig diet.

\begin{tabular}{ccccccc}
\hline $\begin{array}{c}\text { Change in } \\
\text { Price (\%) }\end{array}$ & $\begin{array}{c}\text { Resulting } \\
\text { Price (USD) }\end{array}$ & $\begin{array}{c}\text { Number of } \\
\text { Potential } \\
\text { Buyers in } \\
\text { Masaka } \\
\text { District } \\
\text { (Households) }\end{array}$ & $\begin{array}{c}\text { Number of } \\
\text { Potential } \\
\text { Buyers in } \\
\text { Kamuli } \\
\text { District } \\
\text { (Households) }\end{array}$ & $\begin{array}{c}\text { Quantity of } \\
\text { Silage-Based } \\
\text { Diet Demanded } \\
\text { Annually for } \\
\text { the Two } \\
\text { Districts (Tons) }\end{array}$ & $\begin{array}{c}\text { Percentage } \\
\text { Change in } \\
\text { Annual Demand } \\
\text { for Silage }\end{array}$ & $\begin{array}{c}\text { Estimated } \\
\text { Market } \\
\text { Potential in } \\
\text { Millions (USD) }\end{array}$ \\
\hline 0 & 0.21 & 13,697 & 6833 & 17,679 & 0 & 3.71 \\
7 & 0.22 & 13,060 & 6251 & 16,680 & -6 & 3.75 \\
14 & 0.24 & 8919 & 2907 & 10,475 & -41 & 2.51 \\
21 & 0.25 & 5415 & 2326 & 6737 & -62 & 1.72 \\
29 & 0.27 & 4141 & 727 & 4444 & -75 & 3.20 \\
-7 & 0.19 & 14,334 & 7414 & 18,679 & 6 & 3.63 \\
-14 & 0.18 & 15,290 & 7559 & 19,690 & 11 & 3.31 \\
-21 & 0.16 & 15,290 & 8141 & 20,081 & 14 & 4.99 \\
-29 & 0.15 & 25,165 & 13,810 & 33,327 & 89 &
\end{tabular}

\section{Discussion}

In our study, the mean household size of 5.3 across the two study districts compares well with the national average of about 5 people per household, as reported by the National Population and Housing Census of 2014 [24]. However, looking at our individual districts, households in Kamuli were larger than in Masaka. The higher number of pig units owned by smallholder pig farmers in Masaka compared to the Kamuli district also agrees with the national statistics [7]. The finding that farmers in Masaka owned more improved pig breeds compared to farmers in Kamuli is supported by Ouma et al. [8], who showed that the National Agricultural Advisory Services had helped farmer groups in Masaka to acquire inputs and piglets from improved pig breeds. These findings contribute to an increased confidence in the study results.

Our results suggest that smallholder pig farmers' perceptions of the sweetpotato silage-based diet are primarily shaped by pig performance and the economic benefits to be gained from adopting the new diet. On the other hand, the costs associated with silage production seem to negatively affect farmers' perception of the diets. This finding implies that for sweetpotato silage technology to be widely adopted and scaled, efforts should be made to design and manufacture lower cost choppers and other labour-saving equipment, and to identify business models that provide fee-based chopping services, which would allow several farmers to use a single chopper. Furthermore, the fact that the farmers perceived the chopper as being risky and unsafe suggests the need to completely seal off the blades from the operator's hands and to provide regular training and sensitization activities to ensure that precautions are taken and the risk of injuries minimised (e.g., wearing protective gear during work and using a stick to feed the chopper).

We found that the mean willingness-to-pay price per kilogram of sweetpotato silage-based diet was USD 0.20 . At this price, approximately $43 \%$ and $47 \%$ of the households in Masaka and Kamuli districts, respectively, would be willing to purchase the sweetpotato silage-based diet. The finding suggests that the mean WTP price for a kilogram of sweetpotato silage-based diet was higher than the breakeven price for the silage producer, or USD 0.17. Under these conditions, entrepreneurs of sweetpotato silage-based diet would make a significant profit of USD 0.03 per kilogram.

Key factors that positively influenced farmers' willingness to pay for sweetpotato silage-based diet included the ownership of local pig breeds, which increased farmers' WTP likelihood by $27 \%$. This finding is in line with the work of Ouma et al. [8], who reported that farmers keeping local pigs are often constrained by capital and therefore unable to access both improved breeds and commercial feeds, which makes cheaper feed alternatives like sweetpotato silage-based diet more attractive. 
Farmers' years of experience in pig production were found to raise the probability of their willingness to pay for sweetpotato silage-based diet by $0.6 \%$. This result implies that the cumulative experience gained in pig production enables farmers to appreciate the need to have cheaper and efficient feed alternatives to the existing expensive commercial concentrates, which they have been using for many years. This finding agrees with the conclusion drawn by Wheeler [25], who reported that agricultural professionals with increased experience were more likely to innovate and take risks.

The positive influence of the increase in land under sweetpotato cultivation on farmers' willingness to pay for sweetpotato silage-based diet suggests the importance of accessing large amounts of raw material at low or no cost, and calls for additional investigation of the opportunities for enhancing the integration between crop and livestock systems. Furthermore, this finding may also indicate an increased ability to purchase agricultural inputs and services, as suggested by Abdallah et al. [26], who reported that farmers with large farm sizes are more willing to pay for insurance compared to those with smaller farms.

Unsurprisingly, an increase in the bid price of the silage-based diet reduced the farmers' willingness to pay for it. This result was not unexpected, as it is consistent with the theory of supply and demand, which is expressed as an inverse relationship between the price and the quantity demanded for a commodity by the consumer [27]. More unexpected, however, was the finding that an increased awareness of the silage had a negative influence on farmers' willingness to pay for sweetpotato silage-based diets. This result may be due to a project-related bias, with beneficiary farmers having developed expectations for free provision of inputs and support. This finding also corresponds with Abdullah et al. [28], who indicated that respondents who had been engaged by the national forest research institute were less willing to pay for conservation, as they felt this effort should be funded by the government. However, this finding sharply contrasts with Asrat et al. [29], who found that farmers who were more aware of available agricultural technologies were more receptive and willing to pay more for these technologies. Finally, the finding that increased formal education decreased the farmers' willingness to pay for sweetpotato silage-based diet might indicate that well-educated pig farmers are less capital-constrained and more open to continue purchasing commercial feeds. This finding, however, contradicts some conclusions by Uaiene [30], who found that a high level of education is associated with a higher willingness to pay and an increased propensity to adopt a new technology.

Our study shows that, at the mean WTP price, a substantial market potential for sweetpotato silage-based feed exists-approximately USD 3.59 million. Furthermore, we found that silage entrepreneurs can achieve considerably higher profits by strategically increasing their selling price to USD 0.22. At this price, the quantity of sweetpotato silage-based diet to be supplied would decrease due to fewer potential buyers, but this decrease would be offset by the price increase, resulting in a higher revenue and more sustainable businesses. However, the decision to increase or decrease the price of the sweetpotato silage-based diet should also consider the costs of competing feeds, such as the commercial concentrates, and the resulting unit costs per kilogram of live weight gain for alternative feed options.

\section{Conclusions}

Farmers in the two study districts are willing to pay a mean price of USD 0.20 per kilogram of sweetpotato silage-based diet. At this price, it is estimated that over 20,000 pig-rearing households would be willing to purchase the new diet in the Masaka and Kamuli districts. This change would result in a total annual demand of almost 18,000 tons of sweetpotato silage-based diet from these two districts alone. Furthermore, at this price, SMEs capable of venturing into the silage business would make a reasonable profit and could generate a total annual revenue of approximately USD 3.59 million. Although changes in the prices of alternative feed ingredients may have an impact on the farmers' willingness to pay for sweetpotato silage-based diet and, therefore, on the latter's overall profitability and market demand, a wider adoption of this diet would likely contribute to enhance the business performance of both sweetpotato and pig farmers, reduce the wastage of sweetpotato vines 
and low-quality roots, open up new services and job opportunities, and possibly lower the cost per kilogram of the pork produced. These benefits could be further consolidated and expanded by testing and validating this technology for other livestock, such as goats, cows, rabbits, and sheep. Ultimately, these developments might help to further expand the demand, thus contributing to enabling larger economies of scale and eventually lowering the unit cost of this alternative diet. For these benefits to materialize, it is recommended that additional efforts are made to promote, disseminate, and expand access to this promising innovation. These efforts should include building the capacity of public extension services and adopting participatory approaches that can bring together and facilitate the dialogue among diverse stakeholders, including the integration in several initiatives and programmes focusing on the development of the livestock sector in Uganda and in the region at large.

Author Contributions: Conceptualization, M.A., E.O., G.E., and D.N.; data curation, M.A.; formal analysis, M.A.; funding acquisition, E.O. and D.N.; investigation, M.A.; methodology, M.A. and E.O.; project administration, E.O. and D.N.; supervision, E.O., G.E., and D.N.; validation, M.A. and G.E.; writing-first draft, M.A.; writing-review \& editing, M.A., E.O., G.E., and D.N. All authors have read and agreed to the published version of the manuscript.

Funding: This study was funded by the European Union and IFAD through the project "Expanding Utilization of Roots, Tubers and Bananas and Reducing Their Postharvest Losses (RTB-ENDURE)".

Acknowledgments: This study is an output of the Expanding Utilization of Roots, Tubers and Bananas and Reducing Their Postharvest Losses (ENDURE), a 4-year project (2014-2017) funded by the European Union and implemented with technical support from IFAD. The research has been conducted as part of a collaboration between the CGIAR Research Program on Roots, Tubers and Bananas (RTB) and the CGIAR Research Program on Livestock.

Conflicts of Interest: The authors declare that they have no competing interests.

\section{References}

1. Food and Agriculture Organisation (FAOSTAT). Food and Agriculture Organization of the United Nations; FAO Statistics Division: Rome, Italy, 2016. Available online: http://www.fao.org/faostat/en/\#home (accessed on 13 August 2018).

2. Alexandratos, N.; Bruinsma, J. World Agriculture towards 2030/2050: The 2012 Revision. ESA Working Paper No. 12-03; FAO: Rome, Italy, 2012. Available online: http://www.fao.org/3/a-ap106e.pdf (accessed on 18 March 2020).

3. Motteta, A.; Haanb, C.D.; Falcuccia, A.; Tempioa, G.; Opioa, C.; Gerbera, P. Livestock: On our plates or eating at our table? A new analysis of the feed/food debate. Glob. Food Secur. Agric. 2017, 14, 1-8. [CrossRef]

4. Asindu, M.; Elepu, G.; Ouma, E.; Kyalo, G.; Lule, P.; Naziri, D. Sweet potato wastes in major pig producing districts in Uganda: An opportunity for investment in silage technologies. Livest. Res. Rural. 2017, 29, 1-6.

5. Dione, M.M.; Pezo, D.; Kyalo, G.; Mayega, L.; Nadiope, G.; Lukuyu, B. Perception and practices of farmers on the utilization of sweetpotato, and other root tubers, and banana for pig feeding in smallholder crop-livestock systems in Uganda. Livest. Res. Rural. 2015, 27, 1-8.

6. Food and Agriculture Organisation (FAOSTAT). Food and Agriculture Organization of the United Nations; FAO Statistics Division: Rome, Italy, 2010. Available online: http://www.fao.org/faostat/en/\#home (accessed on 22 February 2016).

7. Uganda Bureau of Statistics (UBOS). The National Livestock Census A Summary Report of the National Livestock Census. 2008. Available online: https://www.ubos.org/wp-content/uploads/publications/05_ 2019THE_NATIONAL_LIVESTOCK_CENSUS_REPORT_2008.pdf (accessed on 10 July 2020).

8. Ouma, E.; Dione, M.; Lule, M.; Pezo, D.; Marshall, K.; Mayega, L.; Kiryabwire, D.; Nadiope, G.; Jagwe, J. Smallholder Pig Value Chain Assessment in Uganda: Results from Producer Focus Group Discussions and Key Informant Interviews; International Livestock Research Institute: Nairobi, Kenya, 2014. Available online: https://agris.fao.org/agris-search/search.do?recordID=QT2016107472 (accessed on 23 May 2017).

9. Peters, D. Assessment of the Potential of Sweetpotato as Livestock Feed in East Africa: Rwanda, Uganda, and Kenya: A Report Presented to The International Potato Center (CIP) in Nairobi; International Potato Center: Lima, Peru, 2008; Available online: http://www.fao.org/fileadmin/templates/agphome/images/iclsd/documents/wk1_c13_ claessens.pdf (accessed on 15 May 2015). 
10. Sankaran, M.; Suresh, K.; Maniyam, N.; Sweet Potato as Animal Feed and Fodder. Fruit, Vegetable and Cereal Science and Biotechnology. Global Science Books. 2012. Available online: http://www.globalsciencebooks.info/ Online/GSBOnline/images/2012/FVCSB_6(SI1)/FVCSB_6(SI1)106-114o.pdf (accessed on 16 April 2020).

11. Khalid, A.F.; Elamin, K.M.; Amin, A.E.; Tameem Eldar, A.A.; Mohamed, M.E.; Hassan, H.E.; Mohammed, M.D. Effect of Feeding Sweet Potato (Ipomoea batatas) Vines Silage on Performance and Milk Production of Nubian Goats. J. Anim. Vet. Adv. 2013, 3, 153-159. [CrossRef]

12. Asindu, M.; Ojakol, J.F.; Lule, M.P.; Naziri, D.; Ouma, E. Economic analysis of sweetpotato silage based diets for smallholder pig farmers in Uganda. In Proceedings of the 6th African Conference of Agricultural Economists, Abuja, Nigeria, 23-26 September 2019; Available online: http://ageconsearch.umn.edu/record/ 295809/files/267.\%20Sweetpotato\%20in\%20Uganda.pdf (accessed on 25 March 2020).

13. Kimenju, S.C.; De Groote, H. Consumers' Willingness to Pay for Genetically Modified foods in Kenya. Presented at the 11th International Congress of the EAAE (European Association of Agricultural Economists), The Future of Rural Europe in the Global Agri-Food System, Copenhagen, Denmark, 24-27 August 2005.

14. Louviere, J.J.; Henshen, A.D.; Swait, D.J. Stated Choice Methods Analysis and Applications; Cambridge University Press: Cambridge, UK, 2010.

15. Yadav, L.; Van Rensburg, T.M.; Kelley, H. A comparison between the conventional state preference technique and inferred valuation approach. J. Agric. Econ. 2012, 64, 405-422. [CrossRef]

16. Hanemann, M.W.; Loomis, J.B.; Kannimen, B.J. Statistical Efficiency of Double-Bounded Dichotomous Choice Contingent Valuation. Am. J. Agric. Econ. 1991, 73, 1255-1263. [CrossRef]

17. Arrow, K.; Solow, R.; Portney, P.R.; Leamer, E.E.; Radner, R.; Schuman, H. Report of the National Oceanic Atmospheric Administration (NOAA) Panel on Contingent Valuation. Fed. Regist. 1993, 58, 4602-4614.

18. Mitchell, R.C.; Carson, T.R. Using Surveys to Value Public Goods: The Contingent Valuation Method; Johns Hopkins University Press: Baltimore, MD, USA, 1989.

19. Hall, D.C.; Hall, J.V.; Murray, S.N. Contingent Valuation of Marine Protected Areas: Southern California Rocky Intertidal Ecosystems. Nat. Resour. Model. 2002, 15, 335-368. [CrossRef]

20. Kimenju, S.C.; Hugo, D.G. Consumers' Willingness to pay for genetically modified food in Kenya. Agric. Econ. Res. Rev. 2008, 38, 35-46. [CrossRef]

21. Shultz, S.; Soliz, B. Stakeholder willingness to pay for watershed restoration in rural Bolivia. J. Am. Water Resour. Assoc. 2007, 43, 947-956. [CrossRef]

22. Chen, H.; Chern, W.S. Willingness to pay for GM Foods: Results from a Public Survey in the USA. In Proceedings of the 6th International Conference on Agricultural Biotechnology, New Avenues for Production, Consumption and Technology Transfer, Ravello, Italy, 11-14 July 2002.

23. Wolfe, K. Estimating Market Potential Check-list. Center for Agribusiness and Economic Development Report 06-08 September 2006. The University of Georgia. Available online: https://athenaeum.libs.uga.edu/ bitstream/handle/10724/18679/CR-06-08.pdf?sequence=1 (accessed on 15 May 2015).

24. Uganda Bureau of Statistics (UBOS), The National Population and Housing Census 2014-Main Report, Kampala, Uganda. 2016. Available online: https:/unstats.un.org/unsd/demographic/sources/census/wphc/ Uganda/UGA-2016-05-23.pdf (accessed on 18 February 2017).

25. Wheeler, S.A. What influences agricultural proffessionals' views towards organic agriculture? Ecol. Econ. 2008, 65, 145-154. [CrossRef]

26. Abdullah, M.A.; Abdullah, A.G.; Darham, S.; Radam, A. Farmer willingness to pay for crop insurance in North West Selangor Intergrated Agricultural Development Area (IADA), Malaysia. J. ISAAS 2014, 20, 19-30.

27. Foster, B. Determining Dynamic Market Equilibrium Price Function Using Second Order Linear Differential Equations. Int. J. Human. Soc. Sci. Res. 2016, 6, 222-230. Available online: https://www.ijhssnet.com/journals/ Vol_6_No_11_November_2016/25.pdf (accessed on 9 June 2018).

28. Abdullah, M.; Mamat, P.M.; Yaacob, R.M.; Radam, A.; Fui, H.A. Estimate the conservation value of biodiversity in national heritage site: A Case of Forest Research Institute Malaysia. Procedia Environ. Sci. 2015, 30, 180-185. [CrossRef] 
29. Asrat, S.; Yesuf, M.; Carlsson, F.; Wale, E. Farmer's Preferences for Crop Variety Traits: Lessons for on-farm Conservation and Technology Adoption. Ecol. Econ. 2010, 69, 2394-2401. [CrossRef]

30. Uaiene, R. Determinants of Agricultural Technology Adoption in Mozambique; International Food Policy Research Institute: Maputo, Mozambique, 2010; Available online: https:/tropicalsoybean.com/sites/default/files/ Determinants\%20of\%20Agricultural\%20Technology\%20Adoption\%20in\%20Mozambique_Uaiene.pdf (accessed on 27 September 2017). 